\title{
The Impact of the COVID-19 Lockdown Restrictions on Mental Health Disorders According Student Status
}

Melissa Macalli ( $\square$ melissa.macalli@u-bordeaux.fr )

University of Bordeaux

Nathalie Texier

Kappa sante

Stéphane Schück

Kappa sante

Sylvana Côté

University of Montreal

Christophe Tzourio

University of Bordeaux

\section{Research Article}

Keywords: COVID-19, lockdown restrictions, student status, mental health disorders, impact of COVID-19

Posted Date: May 18th, 2021

DOI: https://doi.org/10.21203/rs.3.rs-464199/v1

License: (a) This work is licensed under a Creative Commons Attribution 4.0 International License.

Read Full License 


\section{Abstract}

The objective was to compare the frequency of depressive symptoms, anxiety and suicidal thoughts in students and non-students enrolled in the same study in France according to key periods of the COVID-19 epidemic. Students were more likely than non-students to having high scores of depressive symptoms and anxiety, particularly during the $1^{\text {st }}$ and $2^{\text {nd }}$ lockdowns. These findings suggest that restrictive measures i.e. lockdown and curfew have an alarmingly stronger negative impact in students than in nonstudent and underlines the frailty of students' mental health and that greater attention should be given to this population.

\section{Introduction}

The short-term negative impact of the COVID-19 epidemic and lockdown on student's mental health problems is well documented [1-3]. During the 2014-15 Ebola outbreak in West Africa, school and university closures increased the school drop-out rates and had a substantial long-term impact on health [4]. These negative impacts may result in long lasting consequences that will not be resolved, even after the re-opening of schools, and usually begin appearing 4-8 weeks after the initiation of lockdown measures $[5,6]$. It is however uncertain whether students are really at higher risk of mental health disturbances than non-students and if there is a differential impact of lockdown periods over time. Our objective was to compare the frequency of depressive symptoms, anxiety and suicidal thoughts in students and non-students enrolled in the same study in France according to key periods of the COVID-19 epidemic.

\section{Methods}

Our study sample comprised participants in the ongoing web-based Confins cohort (www.confins.org), a prospective population-based study launched in April 2020 addressing the psychological impact of covid19. Participants were recruited via advertisement on traditional and social media. To be eligible, subjects had to be aged 18 or older and to have been confined in France. All participants provided an on-lined informed consent.

Depressive symptoms (PHQ-9 $\geq 10$ ), anxiety (GAD-7 $\geq 10$ ), and suicidal thoughts (occasional or frequent) in the past week, were measured in participants during three recruitment waves corresponding to key periods of the COVID-19 epidemic in France: 1) Period 1: first national lockdown (17th March-11th May 2020); 2) Period 2: no lockdown restrictions (12th May-27th October 2020); and 3) Period 3: second national lockdown and curfew (28th October 2020-25th January 2021).

We compared the frequency of mental health outcomes between students and non-students at each period and we used logistic regression models to adjust for age, gender, marital status, education level, and psychiatric disease history. 


\section{Results}

Among the 3783 participants included, $67 \%(n=2518 ; 59 \%$ students) were recruited during the period 1 , $21 \%$ ( $n=811 ; 64 \%$ students) during the period 2 , and $12 \%(n=454 ; 74 \%$ students) during the period 3 . Students had higher rates of mental health symptoms than non-students at each period (Fig. 1.). There was however a dramatic differential pattern between students and non-students according to the period. Multivariate analyses revealed significant variations in the rates of mental health disorders over time in the student population, but not in the non-student population (Table 1.). Specifically, among students, there was a higher frequency of depressive disorders and anxiety during the 1 st and 2nd lockdowns compared to the 'no lockdown period'. Among non-students, the rates of mental health disorders were relatively stable over time. Students had an about $60 \%$ increased risk of depressive symptoms and anxiety compared to non-students during the $1 \mathrm{st}$ lockdown. The point estimates were even higher during the 2 nd lockdown. In 'no lockdown period', there was no difference between the two groups. There was no statistically significant difference between groups regarding suicidal thoughts at any period. 
Table 1

Prevalence of mental health disorders and association between college student status and depression symptoms $(n=3783)$, anxiety $(n=3783)$, suicidal thoughts $(n=3043)$ according to key periods of the COVID-19 epidemic in France, CONFINS cohort (2020-2021).

\begin{tabular}{|c|c|c|c|c|c|c|}
\hline & \multicolumn{2}{|c|}{ 1st lockdown } & \multicolumn{2}{|c|}{$\begin{array}{l}\text { No lockdown } \\
\text { restrictions }\end{array}$} & \multicolumn{2}{|c|}{ 2nd lockdown } \\
\hline & $\begin{array}{l}\text { Non- } \\
\text { students }\end{array}$ & Students & $\begin{array}{l}\text { Non- } \\
\text { students }\end{array}$ & Students & $\begin{array}{l}\text { Non- } \\
\text { students }\end{array}$ & Students \\
\hline Depression \% (N) & $18.7(193)$ & $\begin{array}{l}36.3 \\
(540)\end{array}$ & $21.4(63)$ & $\begin{array}{l}27.1 \\
(140)\end{array}$ & $27.1(39)$ & $\begin{array}{l}53.6 \\
(166)\end{array}$ \\
\hline Anxiety \% (N) & $15.9(164)$ & $\begin{array}{l}26.4 \\
(393)\end{array}$ & $21.1(109)$ & $\begin{array}{l}20.1 \\
(109)\end{array}$ & $18.1(26)$ & $\begin{array}{l}42.9 \\
(133)\end{array}$ \\
\hline $\begin{array}{l}\text { Suicidal thoughts \% } \\
\text { (N) }\end{array}$ & $7.3(54)$ & $\begin{array}{l}11.9 \\
(142)\end{array}$ & $8.3(22)$ & $11.8(54)$ & $11.1(14)$ & $17.6(46)$ \\
\hline $\begin{array}{l}\text { Logistic regression } \\
\text { results }\end{array}$ & OR & $95 \% \mathrm{Cl}$ & OR & $95 \% \mathrm{Cl}$ & OR & $95 \% \mathrm{Cl}$ \\
\hline \multicolumn{7}{|l|}{ Model 1} \\
\hline Depression & 1.44 & $\begin{array}{l}{[1.10-} \\
1.89]\end{array}$ & 1.24 & $\begin{array}{l}{[0.81-} \\
1.89]\end{array}$ & 2.13 & $\begin{array}{l}{[1.24-} \\
3.66]\end{array}$ \\
\hline Anxiety & 1.52 & $\begin{array}{l}{[1.14-} \\
2.05]\end{array}$ & 0.82 & $\begin{array}{l}{[0.52-} \\
1.29]\end{array}$ & 2.65 & $\begin{array}{l}{[1.46-} \\
4.82]\end{array}$ \\
\hline Suicidal thoughts & 1.59 & $\begin{array}{l}{[0.98-} \\
2.56]\end{array}$ & 1.35 & $\begin{array}{l}{[0.72-} \\
2.55]\end{array}$ & 1.24 & $\begin{array}{l}{[0.56-} \\
2.79]\end{array}$ \\
\hline \multicolumn{7}{|l|}{ Model 2} \\
\hline Depression & 1.59 & $\begin{array}{l}{[1.22-} \\
2.08]\end{array}$ & 1.17 & $\begin{array}{l}{[0.76-} \\
1.80]\end{array}$ & 1.80 & $\begin{array}{l}{[1.04-} \\
3.12]\end{array}$ \\
\hline Anxiety & 1.63 & $\begin{array}{l}{[1.22-} \\
2.18]\end{array}$ & 0.94 & $\begin{array}{l}{[0.59-} \\
1.48]\end{array}$ & 2.25 & $\begin{array}{l}{[1.24-} \\
4.10]\end{array}$ \\
\hline Suicidal thoughts & 1.21 & $\begin{array}{l}{[0.91-} \\
1.60]\end{array}$ & 0.82 & $\begin{array}{l}{[0.42-} \\
1.61]\end{array}$ & 0.99 & $\begin{array}{l}{[0.53-} \\
1.85]\end{array}$ \\
\hline \multicolumn{7}{|c|}{$O R=$ Odds ratio, $\mathrm{Cl}=$ Confidence Interval } \\
\hline $\begin{array}{l}\text { Model } 1 \text { adjusted fo } \\
\text { education level, fam }\end{array}$ & $\begin{array}{l}\text { and gen } \\
\text { tatus aft }\end{array}$ & $\begin{array}{l}\text { Model } 2 \\
\text { Itiple im }\end{array}$ & $\begin{array}{l}\text { sted for } \\
\text { ttion on }\end{array}$ & $\begin{array}{l}\text { ender, } p \\
\text { iatric di }\end{array}$ & $\begin{array}{l}\text { iatric dise } \\
\text { e history }\end{array}$ & history, \\
\hline
\end{tabular}

\section{Discussion}

In this study in which students and non-students were recruited using the same strategy and differed only on mean age and marital status (data not shown), we confirmed that students were more likely than nonstudents to having high scores of depressive symptoms and anxiety. This pattern was particularly strong 
during the 1 st and 2 nd lockdowns, thus suggesting that students are a more fragile group under these conditions. Importantly, whereas period with no lockdown restrictions was accompanied by a clear improvement of mental health outcomes in students, the 2 nd lockdown seemed to have an even higher effect on these outcomes in students. These findings suggest that restrictive measures i.e. lockdown and curfew have an alarmingly stronger negative impact in students than in non-students. This could be explained by the lack of support and social isolation due to university closures [7-8] but underlines the frailty of students' mental health and that greater attention should be given to this population [9].

\section{Declarations}

\section{Funding:}

The i-Share and Confins team are currently supported by an unrestricted grant of the Nouvelle-Aquitaine Regional Council (Conseil Regional Nouvelle-Aquitaine) (grant $N^{\circ} 4370420$ ) and by the Bordeaux 'Initiatives d'excellence' (IdEx) program of the University of Bordeaux(ANR-10-IDEX-03-02). M.Macalli was supported by a PhD grant of the Nouvelle-Aquitaine Regional Council (grant $N^{\circ} 17$ EURE-0019) and by the PhD Digital Public Health Graduate School Program supported within the framework of the PIA3 (Investment for the Future) (project reference: 17-EURE-0019).

\section{Author Contribution:}

MM et CT designed the study. MM conducted the statistical analysis. MM, SC et CT wrote the first draft of the manuscript. All authors contributed to editing and commenting the final version.

\section{Conflicts of interest:}

On behalf of all authors, the corresponding authors state that there is no conflict of interest.

\section{Availability of data and material:}

The datasets used and/or analyzed during the current study are available from the corresponding author on reasonable request.

\section{Ethics approval:}

The study follows the principles of the Declaration of Helsinki and the collection, storage and analysis of the data comply with the General Data Protection Regulation (EU GDPR). The study was approved by the French Committee for the Protection of Individuals (Comité de Protection des Personnes - CPP IDF X, nr. 46-2020) and by the National Commission on Informatics and Liberty (Commission Nationale de I'Informatique et des Libertes) CNIL, nr. MLD/MFI/AR205600).

\section{Consent to participate:}

Students were informed on the nature and purpose of the study and provided on-line consent. 
Acknowledgments:

The authors are indebted to the i-Share operational team, Kappa Santé and Kap Code teams for their expert contribution and assistance.

\section{References}

1. Wathelet, M., et al. Factors Associated With Mental Health Disorders Among University Students in France Confined During the COVID-19 Pandemic. JAMA Netw Open 3, e2025591. 10.1016/j.jaac.2020.05.009 (2020).

2. Li, Y. et al. Mental Health Among College Students During the COVID-19 Pandemic in China: A 2Wave Longitudinal Survey. J Affect Disord 15, 281:597-604. 10.1016/j.jad.2020.11.109 (2021).

3. Debowska, A., Horeczy, B., Boduszek, D., Dolinski, D. A repeated cross-sectional survey assessing university students' stress, depression, anxiety, and suicidality in the early stages of the COVID-19 pandemic in Poland. Psychol Med 2, 1-4. 10.1017/S003329172000392X (2020).

4. Elston, J.W., Cartwright, C., Ndumbi, P., Wright, J. The health impact of the 2014-15 Ebola outbreak. Public Health 143, 60-70. 10.1016/j.puhe.2016.10.020 (2017).

5. Viner, R.M., et al. School closure and management practices during coronavirus outbreaks including COVID-19: a rapid systematic review. Lancet Child Adolesc Health 4, 397-404. 10.1016/S23524642(20)30095-X (2020).

6. Loades, M.E., et al. Rapid Systematic Review: The Impact of Social Isolation and Loneliness on the Mental Health of Children and Adolescents in the Context of COVID-19. J Am Acad Child AdolesC Psychiatry 59, 1218-1239.e3. 10.1016/j.jaac.2020.05.009 (2020).

7. Ma, Z., et al. Mental health problems and correlates among 746217 college students during the coronavirus disease 2019 outbreak in China. Epidemiol Psychiatr Sci 29, e181. $10.1017 /$ S2045796020000931 (2020).

8. Elmer, T., Mepham, K., Stadtfeld, C. Students under lockdown: Comparisons of students' social networks and mental health before and during the COVID-19 crisis in Switzerland. PLOS ONE 15, e0236337. 1371/journal.pone.0236337 (2020).

9. Fegert, J.M., et al. Next generation Europe: a recovery plan for children, adolescents and their families: For the time after the pandemic, we need a vision and investments for the future. Eur Child Adolesc Psychiatry 10, 1-5. 10.1007/s00787-021-01767-w (2021).

\section{Figures}




\section{STUDENTS}

60

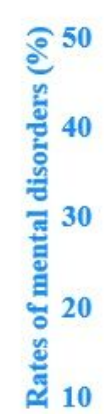

0
NON-STUDENTS

60

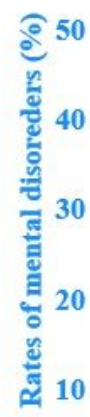

0

Figure 1

Rates of depressive and anxious disorders as well as suicidal thoughts (\%) among students and nonstudents according to key periods of the COVID-19 epidemic in France, CONFINS cohort (2020-2021). 